\title{
EFFECTUATION OF INTERNATIONAL LAW IN THE MUNICIPAL LEGAL ORDER OF THAILAND
}

Kriangsak Kittichaisaree*

\section{INTRODUCTION}

In general, international law has no direct application in the municipal legal order in Thailand. Thailand adheres to the 'dualist' (or 'pluralist') doctrine, according to which the international legal system and the municipal legal system operate on different planes and regulate different subject matters.

Thai jurists are used to codes of law and positive law. There are the Penal Code to govern all aspects of criminal law, and the Civil and Commercial Code to govern all civil matters, such as contracts, torts, and family law. The Criminal Procedure Code and the Civil Procedure Code are there to guide Thai law officers and courts in criminal and civil proceedings. Acts of Parliament have been enacted to supplement these Codes. Apart from certain cases of customary international law, international law finds no direct municipal validity in these realms of positive law - except to the extent that a rule of international law is expressly adopted as part of the law in question.

\section{CUSTOMARY INTERNATIONAL LAW AND GENERAL PRINCIPLES OF LAW}

One distinguished Thai jurist has opined that where there is a lacuna in Thai law, Thai courts resort to three methods to apply international law. First, they construe the Thai law at issue as being in line with customary international law. Secondly, the courts heed certificates, circulars and recommendations of the Ministry of Foreign Affairs, as in cases concerning the issuance of writs to members of foreign diplomatic missions at the time long before the conclusion of the 1961 Vienna Convention on Diplomatic Relations. Thirdly, Thai courts apply general principles of law, such as caveat emptor, volenti non

\footnotetext{
* Minister Counsellor, Royal Thai Embasssy, Washington D.C.

Asian Yearbook of International Law, Volume 4 (Ko Swan Sik et al., eds.; 90-411-0872-6 ${ }^{\circledR} 1995$ Kluwer Law International; printed in Great Britain), pp. 171-184
} 
fit injuria, and actio personalis moritur cum, generally adopted by courts in various countries. ${ }^{1}$ This third method is exemplified by Section 4, second paragraph, of the Civil and Commercial Code. It is here provided that when there is no provision of the Code applicable to the case in point, the latter shall be decided according to the local custom or, in the absence of such custom, the case shall be decided by analogy to the provision most nearly applicable, and in default of such provision, by the 'general principles of law'.

In a similar vein, Section 34 of the Civil Procedure Code provides:

"Where any proceeding is to be carried out wholly or in part through the medium of or by request to the authorities in any foreign country, the Court shall, in the absence of any international agreement or provision of law governing the matter, comply with the general principles of international law".

It has been argued that the 'general principles of international law' are not rules of customary international law, but in fact consist of general practice adopted by the States involved and comity, such as the principle of justice in the taking of evidence, that of convenience, and that of reciprocity in mutual cooperation and assistance. ${ }^{2}$ Since Thai courts turn to general principles of law as a last resort, they are only considered after Thai law, local custom, and analogous provisions of Thai law, in that order.

With regard to customary international law, although there are quite a few sceptics of its direct municipal validity in Thailand, precedents do exist to substantiate such municipal validity, and this is true even in the case of criminal offences where neither the Penal $\mathrm{Code}^{3}$ nor the Criminal Procedure Code makes any reference to some other law as we have seen in civil cases. With regard to diplomatic privileges and immunities, Thailand regarded the 1961 Vienna Convention on Diplomatic Relations as a codification of rules of customary international law on the matter long before Thailand's enactment of the Diplomatic Privileges and Immunities Act in 1984 and its subsequent ratification of the 1961 Convention in 1985. When certain members of a foreign mission were implicated in a drug offence, the Ministry of Foreign Affairs declared them persona non grata and asked them to leave the country,

\footnotetext{
${ }^{1}$ WissanU KRUA-NGam, Application of International Law in the Thai Legal System (Research Report [in Thai language], Chulalongkorn University, Bangkok, 1977) 122-8, 141-2.

2 Ibid, 144-5.

${ }^{3}$ Section 2, paragraph 1, of the Penal Code stipulates: "A person shall be criminally punished only when the act committed by such person is defined as an offence and the punishment is defined by the law in force at the time of the commission of such act, and the punishment to be inflicted upon the offender shall be that provided by the law".
} 
or else they would be stripped of diplomatic immunities and stand trial in Thai courts. The Ministry of Justice Regulation on Service of Judicial and ExtraJudicial Documents of 1979 provides, in Part I, Article 5, that if the Ministry is informed by the Ministry of Foreign Affairs that a person to whom a writ of summons is issued is in fact a person entitled to diplomatic immunities, the Ministry of Justice will inform the court accordingly, so that the court may dismiss the case against that person. Moreover, in the Red Case No.12083 decided in 1983, the court requested the Ministry of Justice to seek an opinion from the Ministry of Foreign Affairs as to whether judgment could be executed against defendant's land on which the Embassy of Bulgaria was situated. This illustrates that Thai courts did respect the inviolability and immunity from execution of the premises of foreign missions under customary international law as enshrined in Article 22 of the 1961 Convention, which Thailand had not yet ratified at the time. Immunities of members of a foreign consular mission are similarly recognized by Thai courts although Thailand has yet to ratify the 1963 Vienna Convention on Consular Relations, and there is no written Thai law according such immunities.

In its Judgment No. 1142 of 1951, the Supreme Court recognized that a Thai warship could exercise the right of hot pursuit on the high seas against a foreign vessel which had violated Thai fisheries law in the Thai fishery zone. No Thai law at that time provided for the right of hot pursuit. Therefore, the Supreme Court could only have resorted to customary international law to reach its decision.

It must be admitted that examples in Thai courts applying customary international law as part of the law of the land are few and far in between. This might be attributable to the difficulty in ascertaining a rule of customary international law in most of the cases before the courts. The case of immunity of members of foreign diplomatic missions and consular posts from both civil and criminal jurisdiction of Thai courts stands out as a unique exception in that customary international law on this matter is unequivocal and indisputable and that courts frequently have to touch on this branch of customary international law. As it will be seen later on, the judgment in 1951 concerning the right of hot pursuit might be an isolated example of Thai courts applying customary international law in an area unrelated to the immunity issue.

Therefore, it cannot be predicted with confidence that Thai courts will in effect grant municipal validity to customary international law as a matter of course whenever an issue before them involves such law. Indeed, it has been a moot point as to how Thai courts would react to a case of foreign sovereign States being sued in Thailand. One cannot simply assume that sovereign immunity would be accorded in line with customary international law or even general State practice. 


\section{TREATIES}

Section 178, second paragraph, of the Constitution of 9 December 1991, stipulates:

"A treaty which provides for a change in the Thai territories or the State jurisdiction area or requires the enactment of an Act for its implementation must be approved by the National Assembly."

Up to the present day, Thailand has had 14 constitutions, and numerous amendments, starting from the first Constitution in 1932, after a coup d'état to transform the absolute monarchy into a constitutional monarchy. The essential difference between these Constitutions lie in the different relationships between the legislative and the executive powers, reflecting the changing situations in Thailand at the time of a particular constitution.

So far as international law and international relations are concerned, the first, and interim, Constitution merely stipulated in Section 36 that the King had the prerogative to ratify treaties of friendship, on the advice of the People's Committee that had staged the coup. It was the second Constitution which followed in the same year that started the now-entrenched tradition regarding municipal validity of treaties as stipulated in Section 178 of the present Constitution. The rationale for this tradition can be gleaned from the debate in the House of Representatives at the time of drafting of the second Constitution. The Executive was recognized as the competent organ to conclude and ratify treaties. However, treaties as such did not bind individual subjects because treaties had legally binding force only on the international plane. Treaties that involved any change in the duties, rights or obligations of the individual subjects thus needed implementing legislation. In order to enact such legislation, however, the Legislature had, logically, to give prior assent to the treaty concerned. ${ }^{4}$ This was a far cry from the days of absolute monarchy when Royal Proclamations were the law of the land and, by proclaiming which treaties were binding on Siam, as Thailand was then called, these Proclamations in effect transformed the treaties into part of the law of the land..$^{5}$

\footnotetext{
${ }^{4}$ Record of the Meetings of the House of Representatives, First Session, 1932, 39th Meeting, Sunday 27 November 1932, pp. 530-4, also quoted at length in WISSANYU KRUA-NGAM, supra n.1, at 131-5.

${ }^{5}$ Cf. Somboon Sangiambut, "Thai Law of Treaties" [in Thai], 31 Saranrom (1981) 141 at 157 8.
} 
In Thailand, there is no distinction or difference in status between selfexecuting and non-self-executing treaties so far as municipal validity in Thailand is concerned. No treaty has direct applicability in Thailand. Where implementing legislation does not exist, treaty obligations merely bind the state through the Executive on the international plane, but not the state organs or subjects in the Thai legal order. For treaty obligations to become law in the municipal sphere, the Executive is obligated to initiate legislation to be adopted by the National Assembly (Parliament), in order to give effect to them. Logically, if the Legislature has already given its approval in case of treaties that need implementing legislation, pursuant to the constitutional requirement mentioned earlier, the Legislature is somehow estopped from disapproving the implementing bills. Only when a new Parliament with a radical change in membership has replaced the preceding one, then the new Parliament might have an excuse not to pass the bills into Acts of Parliament. But this has not yet occurred.

Many treaties merely oblige the State to adopt particular policies, and the issue of legal validity in the municipal sphere consequently does not arise. However, in the case of treaties requiring implementing legislation the National Assembly looks askance at the Executive's attempt to by-pass the Legislature's mandate by having Acts of Parliament enacted in anticipation of Thailand's becoming party to the treaty in question, for fear that the Legislature will be pre-empted from its constitutional role of giving or withholding assent to treaties that by their nature require its approval. Moreover, according to an October 1983 opinion of the Juridical Council, which is a government organ acting as the Executive's chief legal advisers and draftsmen, enacting an Act and giving approval to a treaty are two distinct processes. When reading a bill, the Senate and the House of Representatives, which together constitute the National Assembly, hold sessions separately, whereas they sit in joint session at the time of considering whether to give assent to the treaties that require their approval. As a result, the Cabinet resolved on 20 December 1983 that a treaty which requires implementing legislation shall be submitted to the National Assembly for approval prior to the submission of its implementing bill to the National Assembly. The present Constitution of 9 December 1991 reaffirms the regulation laid down in previous constitutions. Sections 139 and 140 provide that bills have to be submitted first to the House of Representatives before their forwarding to the Senate. On the other hand, Section 156(2) stipulates that the House and the Senate shall hold a joint sitting to approve a treaty that requires assent of the National Assembly.

Recently, an opposition member of the House of Representatives voiced his concern over the Copyrights Bill submitted by the Ministry of Commerce, on the grounds that the Bill was intended to implement Thailand's obligations 
under the GATT's Uruguay Round Agreements, which Thailand has not yet ratified. In his view, this was a thinly-veiled attempt to by-pass the requirement of Section 178, second paragraph, of the 1991 Constitution. The Government's response was that the Bill was not specifically intended to implement the GATT's Uruguay Round obligations as alleged. The GATT's Uruguay Round Agreements had multifarious obligations besides those on copyrights, and the Government was still uncertain about the extent to which Thailand needed implementing legislation in this case.

In fact, the Legislature has enacted numerous pieces of legislation that do not have the main objective of implementing Thailand's treaty obligations prior to the Legislature's endorsement of the treaties pursuant to the constitutional requirement, but with the main objective of keeping Thai law abreast of Thailand's national interests in the light of ever-changing circumstances. Framework or 'enabling' legislation has been passed on many occasions. The Transfer of Prisoners (Execution of Penal Sentences) Act of 1984 is one example. The Act enables Thai courts to apply provisions of the relevant treaties on transfer of prisoners as if they were part of Thai law, be it that these treaties have already been concluded or have yet to be concluded in the future. Similarly, the Measures to Suppress Illicit Drug Offenders Act of 1991 and the Mutual Assistance in Criminal Matters Act of 1992 have been enacted, while a money laundering law is being contemplated - all in line with the provisions of the 1988 UN Convention against Narcotic Drugs and Psychotropic Substances, which Thailand is not yet sure whether it will ratify eventually. In other words, Thai national interests may coincide with most provisions of a treaty without Thailand necessarily being able to accept the treaty obligations in toto. In this situation, an Act of Parliament may be enacted without infringing any constitutional requirement.

Another plausible theoretical explanation is that of a distinguished expert on treaty-making practice in Thailand. In his opinion, legislation implementing treaty obligations may be of either of two types. The first type aims at implementing a specific treaty, whereas the second type aims at simultaneous implementation of various treaties, some of which may have already been in existence while others are to be concluded in the future. In this latter case, of which the 1961 Act to Protect the Functioning of the United Nations and Specialized Agencies in Thailand is an oft-cited example, it is not possible to seek approval from the National Assembly for the whole class of treaties prior to the National Assembly's enactment of the legislation concerned. Such approval can be asked in the case of a specific treaty. Therefore, the Cabinet 
resolution of 20 December 1983 is believed to cover only the case of a specific treaty. $^{6}$

With due respect, practice since 1983 has been too inconsistent to support this explanation. The Diplomatic Privileges and Immunities Act was passed in 1984 to implement the 1961 Vienna Convention on Diplomatic Relations which Thailand did not ratify until 23 January 1985 . With regard to a 'class' or 'group' of treaties, the ordeal of the Extradition Act of 1929 is illuminating. Section 3 of the Act stipulates:

"This Act shall be applicable to all extradition proceedings in Siam so far as it is not inconsistent with the terms of any Treaty, Convention or Agreement with a foreign State, or any Royal Proclamation issued in connection therewith."

Logically, where extradition treaties exist, Thai courts ought to be able to apply their provisions without having regard to any contrary provisions in the 1929 Act since the Act has already authorized the courts to do so. Nonetheless, even before 1983 the Executive played safe by annexing the extradition treaty in question to the extradition bill for the implementation of each particular extradition treaty, such as in the Extradition between Thailand and Indonesia Act of 1979. It was, in fact, the bill to implement the Extradition Treaty between Thailand and the Philippines, of 16 March 1981, that prompted the Cabinet to pass the resolution of 20 December 1983.

At present, where a treaty obligation involves the rights and duties of subjects under Thai municipal law, a bill is usually prepared for its reading in the National Assembly immediately after the National Assembly has approved the treaty which the bill seeks to implement. In one unique situation, an implementing law had to come into force at the same time as the identical legislation in another country. This was the case with the Thailand-Malaysia Joint Authority Act of 1990, which had been harmonized with the MalaysiaThailand Joint Authority Act of 1990 enacted by the Malaysian Parliament. ${ }^{7}$ Pursuant to the Agreement on the Constitution and Other Matters Relating to the Establishment of the Malaysia-Thailand Joint Authority, signed on 30 May 1990 , both countries were to enact identical legislation to implement the

\footnotetext{
${ }^{6}$ Somboon Sangiambut, 'Procedural steps in enacting legislation to implement treaties', 34 Saranrom (1984), 149 at 149-150. Dr. SANGIAMBuT is currently Director-General of the Department of East Asian Affairs of the Ministry of Foreign Affairs. He used to serve as Chief of the Division of Treaties, and as Deputy Director-General of the Department of Treaties and Legal Affairs.

7 Cf. 1 AsYIL (1991) 190, 2 AsYIL (1992) 343, 3 AsYIL (1993) 416.
} 
Agreement, with minor drafting adjustments permitted, which legislation was to enter into force simultaneously in both countries. The provisions of the identical legislation form part of the Agreement. Immediately after the Thai National Assembly had approved the Agreement in joint session, the House and the Senate, in separate sittings, passed the Act. However, the Act did not come into force until its publication in the Government Gazette on 22 January 1991, the day after the Agreement had come into force on the exchange of instruments of ratification. This is also a clear example of a case where the National Assembly is estopped from withholding assent to a bill to give effect to the treaty which it has already approved. The National Assembly could not even amend any provision of the bill in spite of the complaints by some members of the House that the legislation was tantamount to a fait accompli.

On the whole, an obsession with the supremacy of legislation or Thai municipal law over treaties has brought about the dilemma described above. It is interesting to note that treaties entailing financial obligations on Thailand's part need not be submitted to the National Assembly for prior approval despite the fact that the Executive must subsequently submit budget bills to the House to implement such obligations. ${ }^{8}$ This is probably because if a budget bill fails to sail through the National Assembly, the Executive must dissolve the House and call for a general election. Such a situation is not likely to occur so long as the Executive controls the majority in the House and has some support in the Senate. ${ }^{9}$

It follows from the foregoing that an interested legal subject cannot invoke treaty obligations per se in the Thai municipal legal sphere for which there are no counterparts in the prevalent Thai municipal law. In April and May 1994, the Juridical Council had occasion to rule on the rights of an insurance company founded in 1968, 99.84 per cent of whose shares were subsequently owned by an American insurance company. One of the questions was whether, by virtue of Article IV of the Treaty of Amity and Economic Relations between Thailand and the USA, which had entered into force in 1968, the company would be entitled to receive national treatment on a par with Thai insurance companies operating in Thailand, including the right to open branches, or whether the company would not be so entitled since it was a

\footnotetext{
${ }^{8}$ Somboon SANGiambut, supra, n.5, at 146.

${ }^{9}$ Under Sections 141 and 142 of the Constitution of 9 December 1991, if a money bill is withheld by the Senate after it has been approved by the House, the House may forthwith proceed to reconsider it. If the House resolves to reaffirm the original money bill, oranother money bill submitted by a joint committee composed of the representatives of both the House and the Senate, by the votes of more than one half of the total number of existing members of the House, such bill shall be deemed to have been approved by the National Assembly.
} 
subsidiary of a foreign company which the Non-Life Insurance Act of 1992 prohibits from establishing more branches in Thailand in addition to those in existence prior to the enactment of the Act. The Juridical Council, meeting in plenary, ruled, inter alia, that under the long-established tradition of democracy in Thailand and every Thai constitution a treaty was enforceable in Thailand only to the extent that it did not conflict or contradict Thai municipal law or insofar as there existed municipal legislation implementing the treaty's provisions. Although the 1968 Treaty was binding on Thailand, the right conferred under Article IV of the Treaty found no counterpart in Thai insurance law. Therefore, the provisions of the Act of 1992 were held to prevail over the Treaty's provisions, and the insurance company in question could not avail itself of the right accorded by the Treaty. Most interestingly, the Juridical Council ruled that this has been the traditional practice in Thailand even though the 1968 Treaty came into force during the life of the interim Constitution of 1959 which did not lay down any rule on treatymaking, unlike the other constitutions since the time of the second Constitution of 1932. On 16 August 1994, the Cabinet endorsed the Juridical Council's ruling.

That there must be adaptation of the international to the municipal legal structure, notions and terminologies is manifest from the example of the Royal Proclamation dated 29 April 1969, proclaiming that the four Geneva Conventions on the Law of the Sea of 1958 are binding on Thailand.

By virtue of Article 24 of the 1958 Geneva Convention on the Territorial Sea and the Contiguous Zone, coastal States may exercise certain jurisdiction in the contiguous zone. Yet, up to the present day the relevant Thai law enforcement authorities have been pressing for an Act of Parliament on the contiguous zone in order to bring Article 24 of the 1958 Convention to life. It might be, of course, that the provisions of the 1958 Conventions on the law of the sea are too ambiguous or vague for Thai law officers to understand. Another and more valid reason is, however, that the provisions of the Conventions need to be 're-enacted' as Thai legislation before they are enforceable.

Although Royal Proclamations at the time of the absolute monarchy caused a treaty to become the law of the land, under the constitutional monarchy Royal Proclamations merely inform the public that Thailand has become a State Party to a treaty. On the other hand, Thai legislation in whatever form and however named binds subjects under Thai law irrespective of Thailand's international obligations. For instance, Thai law officers have had no difficulty with the Diplomatic Privileges and Immunities Act of 1984 which prescribes that diplomatic privileges and immunities as provided in the 1961 Vienna 
Convention on Diplomatic Relations shall be accorded to those qualified under the Convention, while Thailand had not ratified the Convention until 23 January 1985. It is also fascinating to note the 'unenforceability' in Thailand of the provisions of the 1958 Geneva Conventions, some of which, including those on the contiguous zone, have become part of customary international law.

\section{RESOLUTIONS OR DECISIONS OF INTERNATIONAL ORGANIZATIONS}

Resolutions or decisions of international organizations are generally treated as merely hortatory without any international legal binding force. Even if they had, they would not have direct municipal validity in Thailand. UN General Assembly or Security Council resolutions, such as resolutions on the boycott of oil export and arms embargo against South Africa and those on sanctions against Haiti, are adopted by resolutions of the Thai Cabinet. They are given the force of law through already existing provisions of an Act of Parliament that empower the Minister in charge of the application of the Act to proscribe trading between Thai nationals and a foreign State for reasons of, inter alia, national security and national interests. This was the case of the Cabinet Resolution of 16 August 1994 on trade embargo against Haiti. The embargo is to be carried out by virtue of the Export and Import of Goods Act of 1979, which empowers the Ministry of Commerce to control import and export of goods for certain purposes.

\section{LEX SUPERIORI DEROGAT LEX INFERIORI}

As the Thai legal system follows 'dualism' between international and municipal law, the relative status or rank of these laws in the municipal legal sphere is easy to find.

The Constitution is the supreme law of the land. Section 5 of the Constitution of 9 December 1991 provides: "The provision of any law which is contrary to or inconsistent with the Constitution shall be unenforceable". The supremacy of the Constitution is followed in hierarchy by Acts of Parliament (including codes of law and Ministerial Regulations issued by virtue 
of Acts of Parliament), Emergency Decrees, ${ }^{10}$ and Royal Decrees (or Royal Proclamations), respectively. In each group, lex posteriori derogat priori ${ }^{11}$ and lex specialis derogat generali. If treaty provisions or resolutions/decisions of international organizations are transformed into Thai municipal law in the form of Acts of Parliament, Emergency Decrees or Royal Decrees, the same rule applies. If international law of whatever source, be it customary international law or a treaty or a resolution/decision of an international organization, is in conflict with existing municipal law, municipal law prevails. However, it is widely felt, though there is no concrete evidence to substantiate it besides the previously mentioned cases of diplomatic and consular immunities, that, wherever possible, Thai courts will avoid construing Thai municipal law in flagrant violation of Thailand's legal obligations on the international plane.

On the other hand, the Executive has been at pains to avoid infringing international law, be it a rule of customary international law, a treaty obligation, or a resolution of an international organization, insofar as it does not contradict overriding national interests. Before a law is enacted, it has to be scrutinized by the Juridical Council. The Juridical Council pays due attention to Thailand's relevant international obligations and to de lege lata as well as de lege ferenda international legal rules. For instance, as far back as 1952, the Juridical Council advised the Executive against submission of a bill to the National Assembly, on the grounds that such bill would restrict the right to resort to judicial redress contrary to Articles 8 and 10 of the Universal Declaration of Human Rights of 1948, which the Executive had declared as a matter of policy that it would respect. ${ }^{12}$ More recently, the Juridical Council

\footnotetext{
${ }^{10}$ An Emergency Decree is issued by the King for the purpose of maintaining national and public safety or national economic security or averting public calamity. The Decree has the force of an Act. In the next succeeding sitting of the National Assembly or in an extraordinary session of the National Assembly if waiting for an ordinary session would be a delay, the Cabinet must submit the Emergency Decree to the National Assembly for reaffirmation. If an Emergency Decree has the effect of amending or repealing provisions of any Act and if such Emergency Decree lapses because it is not reaffirmed by the National Assembly, the previous provisions of the Act before its amendment or repeal by the Emergency Decree shall continue to have the force of law as from the effective date of the National Assembly's disapproval of such Emergency Decree. (Section 172 of the Constitution of 9 December 1991.)

Pursuant to Section 175 of the Constitution, the King has the prerogative of issuing a Royal Decree 'which is not contrary to the law'.

${ }^{11}$ With regard to an Emergency Decree, it prevails over the preceding Act of Parliament unless and until the Emergency Decree lapses on its disapproval by the National Assembly.

${ }^{12}$ The bill in question sought to permit the Registrar of Associations to terminate an association for certain purposes without the association's right to a judicial review. See WISSANU KRUANGAM, supra $\mathrm{n} .1$ at $112-6$.
} 
advised the Cabinet that the Thai Fisheries (Amendment) Bill needed to be modified and revised so as to be compatible with the relevant provisions of the 1982 UN Convention on the law of the Sea, which Thailand has not yet ratified but in respect to which Thailand has an obligation as a signatory not to defeat its object and purpose. The Cabinet heeds advice of the Council, and, more often than not, so does the Legislature when the latter reads opinions of the Council submitted in connection with a bill. Once a law has been enacted, however, courts must apply the Thai law even if that may violate Thailand's international obligations. This was made clear in the Supreme Court's Judgment No. 4941 of 1967. The plaintiff in that case argued that Section 17 of the Constitution (Amendment) of 1965, which prohibited any law suits against the Prime Minister and those acting under his orders, was in violation of the Universal Declaration of Human Rights. The Supreme Court held that such argument was relevant at the time of drafting the Constitution, but not after the Constitution had been promulgated. ${ }^{13}$

Under customary international law, as encapsulated in Articles 27 and 46 of the 1969 Vienna Convention on the Law of Treaties, a State may not invoke the provisions of its internal law as justification for its failure to perform a treaty, unless it is objectively evident to any State conducting itself in the matter in accordance with normal practice and in good faith that the former State's consent to be bound by a treaty has been expressed in violation of a provision of its internal law of fundamental importance regarding competence to conclude treaties. Thailand's failure to perform treaty obligations entails State responsibility. However, it has not yet been put to the test whether the Executive could cite Articles 27 and 46 in defence of its failure to have implementing legislation enacted by the National Assembly as required by the Constitution, an obviously fundamentally important legal instrument on the issue. Nor has an occasion arisen whereby the Executive cites Article 47 of the 1969 Convention ${ }^{14}$ as a defence that the constitutional restriction was notified to the other negotiating State(s) prior to the Thai Government expressing its consent to be bound by the treaty in question. This is because the Executive has been careful to sign treaties ad referendum, pending fulfilment of constitutional requirements, or to ratify or accede to treaties only after constitutional requirements have been fulfilled.

\footnotetext{
${ }^{13}$ Quoted in ibid. at 116-7.

${ }^{14}$ Art. 47 reads: "If the authority of a representative to express the consent of a State to be bound by a particular treaty has been made subject to a specific restriction, his omission to observe that restriction may not be invoked as invalidating the consent expressed by him unless the restriction was notified to the other negotiating States prior to his expressing such consent".
} 
Thai courts are the ultimate organ to decide a specific case before them. Only Acts of Parliament may be subsequently enacted to rectify any undesirable situation caused by court judgments.

It should be noted in this connection that courts may use treaties as factual evidence when determining a case at hand. In the past, Thai courts were involved in treaty interpretation to limit, as far as possible, the geographical areas over which the foreign Powers had extraterritorial jurisdiction over their subjects pursuant to the treaties whereby Siam ceded such extraterritorial jurisdiction to the Powers. ${ }^{15}$ Therefore, it is inconceivable that courts of the present time would ignore relevant treaties as representing a state of affairs for them to bear in mind if necessary. For example, the courts are most unlikely to ignore maritime boundary treaties between Thailand and neighbouring states in determining the outer limits of the Thai territorial sea (which falls within the definition of 'the Kingdom of Thailand' within which all Thai law applies), and that of the continental shelf, or the exclusive economic zone whose area falls under the application of the Petroleum Act of 1971 and the Fisheries Acts, respectively. The judgment of the International Court of Justice in The Temple of Preah Vihear Case (Cambodia-Thailand) ${ }^{16}$, which held that a temple on a cliff on the Thai-Cambodian border was situated in the territory under the sovereignty of Cambodia should have the same effect as factual evidence in Thai courts. ${ }^{17}$

\section{CONCLUSIONS}

The foregoing study of effectuation of international law in the Thai municipal legal order leads to the following conclusions:

(1) In general, international law has no direct application in the Thai municipal legal order.

\footnotetext{
${ }^{15}$ Supreme Court Judgments Nos. 606-607 of 1943, Nos. 674-679 of 1943, and No. 1315 of 1947, cited in WISSANU KRUA-NGAM, supra n.1 at 146-8.

${ }^{16}$ I.C.J. Reports 1962 p. 6.

${ }^{17}$ The Thai Government circulated protests against the Judgment on the grounds that the opinions of the majority of the Court which ruled against Thailand were not well-founded either in fact or in law. Phrased differently, Thailand refused to comply with the decision of the Court in this case to which it was a party, contrary to Article 94 of the Charter of the United Nations.

When irredentists' emotions subsided, the Thais gradually accepted the Court's Judgment. There is no evidence that any law has been enacted to implement the Judgment, which, in any case, concerns a remote and uninhabited area near the border. The Government of the day just ordered Thai troops to pull out of the area.
} 
(2) General principles of (international) law are applied as last resort by Thai courts to fill in a legal lacuna.

(3) There are precedents that ascertainable rules of customary international law, especially those concerning diplomatic and consular immunity, have been adopted by Thai courts. However, the extent to which Thai courts adopt rules of customary international law is generally far from certain.

(4) Thai municipal law prevails over treaty obligations. In order to be enforceable in the Thai municipal order, treaty provisions must be transformed into Thai municipal law, unless implementing legislation already exists.

(5) Resolutions or decisions of international organizations can be binding in the Thai municipal legal order only if they are transformed into Thai law or are given the force of law through already existing provisions of an Act of Parliament.

(6) Under Thai law, lex posteriori derogat priori and lex specialis derogat generali. Thai courts are the ultimate organs to settle any conflict between international law of whatever source and existing municipal law. Longestablished jurisprudence reveals that municipal law prevails over conflicting international law. However, the Executive and, to some extent, the Legislature have endeavoured to prevent conflicts between international law and municipal law.

(7) Treaties and a judgment of the International Court of Justice binding on Thailand may be used as factual evidence before Thai courts when determining a case at hand. 